\title{
Sediment Discharges from Ghanaian Rivers into the Sea
}

\author{
S.A.Akrasi \\ CSIR-Water Research Institute, P. O. Box M.32, Accra, Ghana \\ Correspondingauthor;E-mail: samteakrasi@yahoo.com
}

\begin{abstract}
Information on sediment yield of a river basin is an important requirement for water resources development and management. In Ghana, data on suspended sediment yield are limited owing to lack of logistic support for systematic sediment sampling activities. The paper presents the results of a study, using measurements of suspended sediment transport for 21 monitoring stations in southern Ghana to develop simple predictive models for suspended sediment yields of catchments for which no sediment measurements had been undertaken. Regression analysis was used to establish a relationship between specific suspended sediment yield and both the mean annual runoff, and the drainage basin area. One of the prediction models was used to estimate the sediment loads of the southern Ghana rivers and total suspended sediment discharges into the sea, in addition to specific suspended sediment yields from the drainage basins. The specific suspended sediment yield for the south-western and coastal basin systems ranged between 11 and $50 \mathrm{t} \mathrm{km}^{-2} \mathrm{year}^{-1}$. The annual sediment discharges into the sea by the rivers ranged between 15,000 and $1.2 \times 10^{6} \mathrm{t}$, and total yearly sediment discharge into the sea by Ghanaian rivers is estimated to be $2.4 \times 10^{6} \mathrm{t}$.
\end{abstract}

\section{Introduction}

Sediment particles are transported through river system as a result of runoff from rainfall through the processes of sheet, rill and gully erosion. The eroded sediment particles are eventually deposited in a flood plain, reservoir or sea.

Many activities related to the conservation, development and utilization of land, mineral and water resources either increase or decrease the rate of sediment movement, thereby, causing a variety of sediment related problems. A change in runoff regime from a drainage basin, for example, may concentrate or disperse sediments in the stream channel and, in turn, affect the flow capacity of the stream. Because of the complex interrelationship that affects erosion, transport and deposition, knowledge of climate, physical attributes of drainage basins, hydraulic and hydrologic characteristics of stream flow, and quantitative and qualitative aspect of sediment are all required to solve sediment problems.
Sediment yield data are very limited in the river basin systems of Ghana owing primarily to lack of logistics and the high cost involved in sediment data collection. Simple sediment yield predictive models have been developed, using the suspended sediment discharge measurements that has been carried out in the basins, to be used to estimate sediment yields of ungauged river basins in Ghana. Sediment yield predictive models have been developed for the southwestern river basins (Amisigo \& Akrasi, 2000), the Volta basin system (Akrasi, 2005) and the Pra river basin (Akrasi \& AnsaAsare, 2008) using runoff and catchment area.

Modelling is an important research tool. Planning and management of soil and water resources of a nation require knowledge of factors that cause loss of soil and water and those that tend to minimise such losses. Erosion and sedimentation by water involve the processes of detachment, transport and deposition of soil particles. Sediment yield on a Ghanaian catchment includes soil 
erosion from agricultural fields, hill slopes and settlements. Factors that influence fluvial sediment loads would, therefore, include the various land uses and cultural practices that take place in these areas. Since it is not practicable to undertake field measurements of the effects of these practices on sediment yield, predictive models are used. Good sediment yield models could provide good estimates of the rates at which drainage basins are contributing sediment to the rivers. They could also be used to predict the effects of various combinations of land use activities and cultural practices on erosion and sediment yield on drainage basins.

The study reported in this paper is a collation of sediment yield data in southwestern and coastal basin systems. The objective is to develop simple models to estimate suspended sediment yields of the catchments within the south-western and coastal basins, and to use the models to estimate the total sediment loads being discharged into the sea.

\footnotetext{
Materials and methods

Study area

The south-western basin system is humid with annual rainfall in the range of 1500-2000 $\mathrm{mm}$, with vegetation consisting of tropical rain forest and moist semi-deciduous forest. It is located at the extreme south-western corner of the country. Soils of the tropical rainforest are forest oxysols, which is acidic, and that of the semi-deciduous forest is forest ochrosols, which is alkaline and well drained. The basin is underlain by pre-Cambrian formation, and is classified into Birrimain and Tarkwaian rocks. Major rivers draining the southwestern basin system are Bia (enters the sea in La Cote d'Ivoire), Tano, Ankobra and Pra.
}

The coastal basin system (dry equatorial) is relatively dry, with annual rainfall values ranging between 740 and $890 \mathrm{~mm}$ (Dickson $\&$ Benneh, 1980). The vegetation within the basin falls into two zones: semi-deciduous forest in the northern part of the basin, and coastal savanna and grassland along the coast. Forest and coastal savanna ochrosols, lateritic sandy soils, tropical black clays, sandy soils, tropical grey earth and coastal sands constitute soils of the basin. The underlying rock formation is also preCambrian. Rivers draining the coastal basin system are Amisa, Nakwa, Ayensu, Densu and Tordzie.

The study comprised three major components. First, the available suspended sediment measurements for 21 monitoring stations in the south-western and coastal river systems were collated and used to estimate the mean annual suspended sediment yields of the sub-basins controlled by the stations. Second, the data were used to develop simple empirical prediction models for estimating the suspended sediment yield of other ungauged basins within the south-western and coastal river systems. Third, the derived sediment prediction models were used to estimate the sediment yields of the major rivers entering the sea and the total sediment discharge into the sea.

The available sediment data comprised measurements of the suspended sediment concentrations of water samples, collected without the use of depth-integrating suspended sediment sampler. Instead, improvised point sampler, similar to the dipping of ordinary sample bottle, was used to collect samples from the surface (Akrasi \& Amisigo, 1993; Akrasi, 2008). It is well known that the concentration obtained for a 


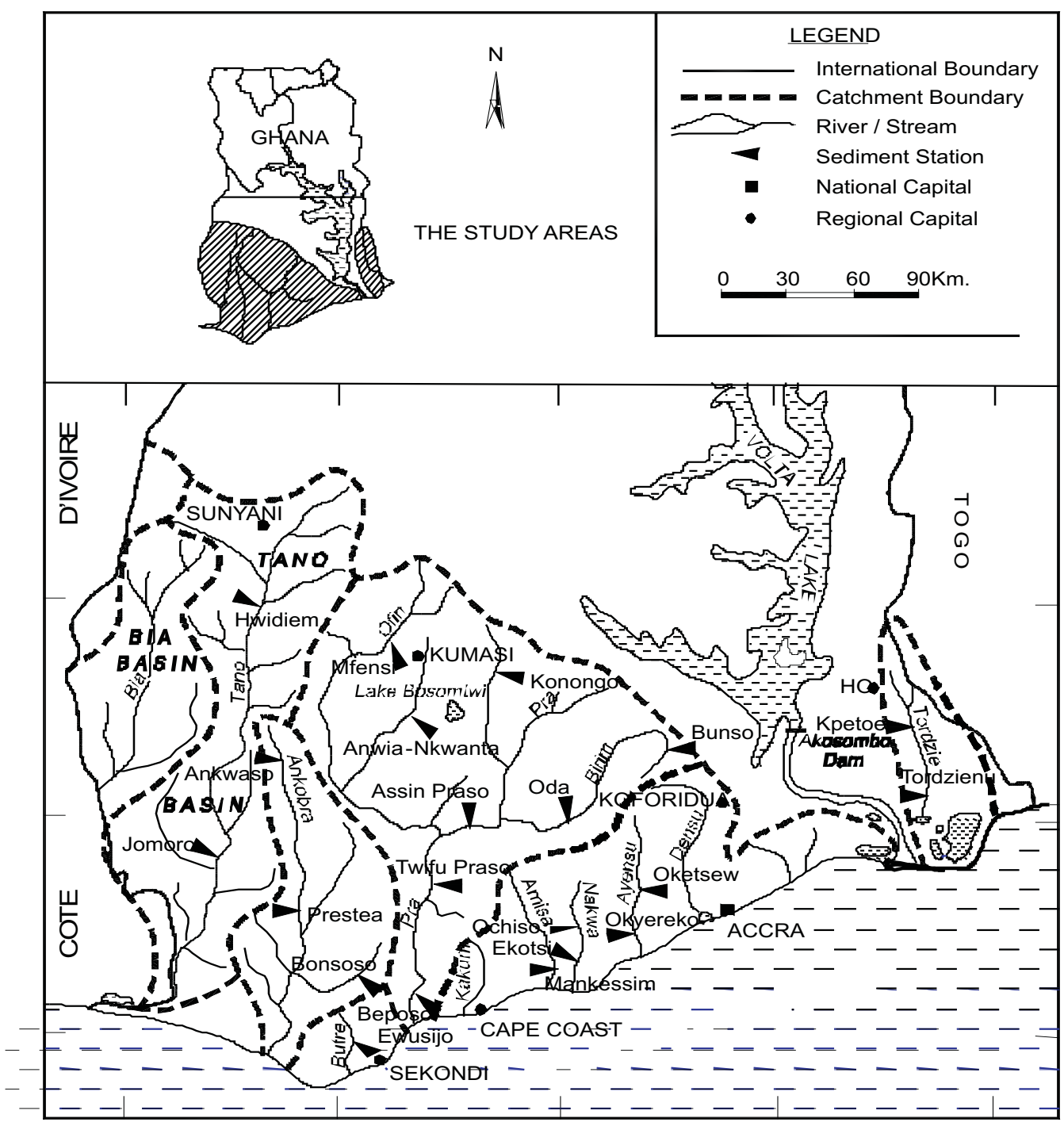

Fig. 1. The map of the south-western and coastal basin system of Ghana showing sediment sampling sites

suspended sediment sample collected from the water surface is likely to underestimate the mean concentration in the vertical or the overall cross-section (Demmak, 1976; Rooseboom \& Annandale, 1981). This is because the sediment concentrations are usually greatest near the river channel bed, decreasing as one move toward the water surface.

In the absence of specialist depthintegrating or point-integrating samplers, which could be used to derive correction factors for taking into account the degree of underestimation associated with samples 
collected at the surface by dipping, reference was made to other studies that have attempted to establish such correction factors. Rooseboom \& Annandale (1981) reported the results of a study undertaken in South Africa aimed at comparing the magnitude of the suspended sediment concentrations associated with surface dip samples with the mean values for vertically derived samples collected with a more sophisticated Turbisonde sampler. In the study, the concentrations associated with the surface samples were approximately $25 \%$ less than the mean value for the vertical samples.

A similar study, undertaken by Demmak (1976) at the Sidi Bel Alter gauging station on the Oued Cheift in Algeria, compared the instantaneous suspended sediment load, calculated using the concentration value obtained for surface-suspended sediment samples, collected near the edge of the channel with the load estimate derived, using detailed sampling in the cross-section with the Neyrpic Turbisonde sampler method, concluding that the former underestimated the load by approximately $25 \%$.

The precise magnitude of any correction factor can be expected to vary according to both the grain size composition of the sediment and the hydraulic conditions within the channel (e.g. velocity, roughness and turbulence). In the absence of site-specific information, however, a correction factor of $25 \%$ was used and the measured values of the suspended sediment concentrations obtained for surface dip samples collected near the channel edge were increased by $25 \%$ to provide mean concentration values for the cross-section area.

The suspended sediment concentration data for 21 sediment sampling stations comprised 15-66 measurements, undertaken on infrequent samples collected at different times of the year over a representative range of water discharges. The sampling frequency of these data was insufficient to interpolate the sediment concentration record for the period of sampling. Thus, the rating curve technique (Walling, 1977) was used to estimate the mean annual suspended sediment yield at the sampling sites. For each site, the measured values of suspended sediment concentration (corrected) and discharge were used to establish a rating relationship:

$$
Q=k Q_{w}^{n}
$$
where $Q=$ sediment discharge $\left(\mathrm{t}\right.$ day'),$Q_{w}=$ water discharge $\left(\mathrm{m}^{3} \mathrm{~s}^{\prime \prime 1}\right), n=$ exponent and $k=$ constant.

As these rating relationships were established using least squares regression on the log-transformed values of sediment discharge and water discharge, their use in estimating the sediment loads associated with individual discharge values is likely to result in a bias towards underestimation (Ferguson, 1986). As a result, the bias correction factor proposed by Ferguson (1986) was applied to the resulting load estimates. These rating curves were used in conjunction with the longer-term flow duration curves for the measuring stations in order to estimate the mean annual sediment yields for these stations (Miller, 1951; Walling, 1977). These flow duration curves were based on mean daily flows. The use of daily mean flow data to estimate the sediment loads of the 21 sampling stations is unlikely to introduce significant errors, as most of the catchments associated with the measuring stations are relatively large. 
The existing information, however, shows the suspended sediment regimes of the study catchments, and are characterized by extended periods of high flow with elevated suspended sediment concentrations during the wet season, rather than a flashy response characterized by short-lived flood events. The mean annual specific suspended sediment yields of the 21 stations were derived by dividing the mean annual load by the catchment area.

The values of specific suspended sediment yield obtained for the 21 measuring stations, using the method described above, were subsequently used to develop simple empirical prediction models for estimating the specific suspended sediment yields of catchments within the south-western and coastal river system, for which no sediment measurements were available. These simple empirical prediction models were derived by using multiple regression analysis to relate the available values of specific suspended sediment yields to a range of variables, representing catchment characteristics likely to influence the spatial variability of specific suspended sediment yield within the southwestern and coastal river system.

In view of the small number of sediment yield values available to parameterize the model, it was important to keep the number of independent variables as small as possible, in order to increase the statistical significance of the resulting regression equation. Both the dependent and independent variables were $\log$ transformed, with the resulting prediction equation:

$$
S_{y}=K U_{1}^{a} U_{2}^{b} \ldots \ldots . U_{n}^{z}
$$

where $S_{y}=$ the mean annual specific suspended sediment yield ( $\mathrm{t} \mathrm{km}^{\prime 2}$ year"1 $), K=$ the regression constant, and $U_{1}, U_{2} \ldots \ldots U_{n}=$ the independent variables. The statistical significance of the resulting prediction models were assessed using the coefficient of determination and by testing the significance of the regression coefficients, using the $F$-test (Yamane, 1970).

\section{Results and discussions}

Table 1 gives the summary of rating relationships developed from the suspended sediment concentration data collected for the 21 monitoring stations. Each relationship was statistically tested to be significant at 5\% level. Coefficients of determination $\left(r^{2}\right)$, associated with the relationships, range between 0.81 and 0.91 . The relatively low magnitude of the rating exponents (0.64-1.50) reflects the insensitivity of suspended sediment concentration to increases in discharges. The exponent values presented in Table 1 are substantially lower than the typical values between 2.0 and 3.0, cited by Gregory \& Walling (1973). These low exponent values suggest that the rivers remain turbid over a wide range of flows, and the suspended sediment concentrations remain relatively high during low flows.

The situation also could reflect the relatively low gradient of the river systems and the importance of localized storms in generating local sediment inputs to the river systems, which are essentially unrelated to the overall water discharge regime. Further work is required to explore the localized storm, which is a key feature of the sediment response of the south-western and coastal river systems in more detail. In the case of the Ofin river at Dunkwa, the exponent of the sediment load discharge relationship is less than 1.0, indicating the concentrations tend to decrease when the discharges increase. The decrease in concentrations when discharges increase is further emphasized by the 
TABLE 1

Parameters for Equation 2

\begin{tabular}{|c|c|c|c|c|}
\hline Station & River & $k$ & $n$ & $r^{2}$ \\
\hline Hwidiem & Tano & 2.540 & 1.500 & 0.87 \\
\hline Jomuro & Tano & 4.195 & 1.211 & 0.93 \\
\hline Ankwaso & Ankobra & 6.368 & 1.054 & 0.88 \\
\hline Prestea & Ankobra & 5.322 & 1.003 & 0.85 \\
\hline Bonsaso & Bonsa & 2.805 & 1.143 & 0.92 \\
\hline Ewusijo & Butre & 1.072 & 1.197 & 0.85 \\
\hline Mfensi & Ofin & 1.363 & 1.328 & 0.81 \\
\hline Anwia-Nkwanta & Ofin & 5.514 & 1.135 & 0.86 \\
\hline Dunkwa & Ofin & 138.400 & 0.640 & 0.45 \\
\hline Bunso & Birim & 1.423 & 1.305 & 0.84 \\
\hline Oda & Birim & 4.086 & 1.105 & 0.90 \\
\hline Konongo & Anum & 3.132 & 1.128 & 0.91 \\
\hline Assin-Praso & Pra & 1.083 & 1.331 & 0.90 \\
\hline Twifu-Praso & Pra & 4.473 & 1.137 & 0.86 \\
\hline Beposo & Pra & 5.753 & 1.099 & 0.89 \\
\hline Mankesim & Amisa & 6.250 & 1.100 & 0.89 \\
\hline Ekotsi & Nakwa & 6.606 & 1.110 & 0.86 \\
\hline Ochiso & Nakwa & 2.620 & 1.468 & 0.85 \\
\hline Okyereko & Ayensu & 9.412 & 1.033 & 0.84 \\
\hline Oketsew & Ayensu & 3.333 & 1.205 & 0.85 \\
\hline Tordzienu & Tordzie & 6.635 & 1.101 & 0.79 \\
\hline Kpetoe & Tordzie & 3.499 & 1.284 & 0.84 \\
\hline
\end{tabular}

widespread evidence of dredging activities for gold in the Ofin river at Dunkwa.

The multiple regression analysis of the data sets gave the relations:

$$
S_{y}=0.09 Q_{w}^{0.854} A^{0.228}, r^{2}=0.77
$$

Model 1 is for all the rivers in the basins in the south-western and coastal river systems, including Pra river basin:

$$
S=0.03 Q_{w}^{1.018} A^{0.138}, r^{2}=0.86
$$

Model 2 is for the rivers in the south-western and coastal basin system, excluding Pra river basin:

$$
S_{y}=3.9 \times 10^{-5} Q_{w}^{1.438} A^{0.757} r^{2}=0.91
$$

Model 3 is for the rivers in the coastal basin

$$
S_{y}=0.014 Q_{w}^{1.139} A^{0.141,} r^{2}=0.91
$$

Model 4 is for the rivers in the south-western basin,

where $Q=$ mean annual run-off (mm), and $A=$ catchment area $\left(\mathrm{km}^{2}\right)$.
The corrected coefficients of multiple determination, $r^{2}$ ranges from 0.79 to 0.91 . This is an indication that the variables, runoff and catchment areas accounted for a large proportion of the variance of the suspended sediment yield. The coefficients 0.858 and $0.228,1.018$ and $0.138,1.438$ and 0.757 , and 1.386 and 0.141 , were statistically tested to be significant at 5\% significance level. The established models (1-4) can be used to predict specific suspended sediment yield at any cross-section within the drainage basins with no sediment data. The mean annual runoff $(\mathrm{mm})$ and the catchment area $\left(\mathrm{km}^{2}\right)$, can also be used to estimate the total suspended sediment discharge of the river into the sea.

The positive exponent associated with the 
mean annual runoff in the models indicates that specific suspended sediment yields increase in areas with higher mean annual runoffs, in turn, reflecting the increased erosion and suspended sediment transport associated with the increased runoff. Although the relationship between the specific suspended sediment yield and the catchment area has traditionally been viewed as being negative (Walling \& Webb 1996), the positive relationship obtained in the study is consistent with a number of studies (Dedkov, 2004) that have demonstrated that a positive relationship can occur when channel erosion is an important sediment source. The positive relationship reported by Dedkov (2004) has been explained in terms of the increased discharges and, therefore, the energy available for channel erosion as the catchment area increases.

The negative exponent is commonly explained in terms of the increasing opportunity for sediment deposition and storage, both on the slopes of a catchment and within the channel system, as the catchment area, and travel distances and times increase. The positive exponent for the catchment area term determined in this study probably reflects the increased importance of channel erosion, in the larger rivers in response to both the increased discharges and the more extensive areas of alluvial deposition, which can be remobilized by channel erosion associated with larger drainage basins. The mean runoff is a measure of the sediment transport capability of the runoff, ,and these results indicate that transport capacity is a very important factor influencing specific suspended sediment yield in the basin.

The ability of the simple models (1-4) for predicting the specific suspended sediment yields of a river in the south-western and coastal basin system is further demonstrated with the plots of predicted versus observed specific suspended sediment yield for the catchments above the 21 gauging stations, for which sediment yield data were measured, as presented in Fig. 2-5. All the observed specific suspended sediment yield values are closely matched by the predicted values obtained with the models (1-4). Thus, the models $(1-4)$ can be used to provide an estimate of the specific suspended sediment yield for the respective river basins within the south-western and coastal river basin systems of Ghana, for which suspended sediment data are lacking, provided information on the catchment area and the mean annual runoff is available.

Model 1 was developed using all the data in the south-western and coastal basin systems, including the Pra river basin, and it is the predictive model which was used to determine the suspended sediment discharge into the sea. Though it is the model that predicts the least, it is the only model that covers a wide range of catchment areas. Model 2 was developed to predict suspended sediment yield in the south-western and coastal basin system, excluding the Pra river basin (Bia, Tano, Ankobra, Butre, Amisa, Nakwa, Ayensu, Densu and Tordzie). Model 3 was developed to predict suspended sediment yield in the coastal river basins (Amisa, Nakwa, Ayensu, Densu and Tordzie), whereas model 4 was developed to predict suspended sediment yield in the south-western river basins (Bia, Tano, Ankobra and Butre).

The simple predictive tools afford a means of establishing the probable spatial variation 


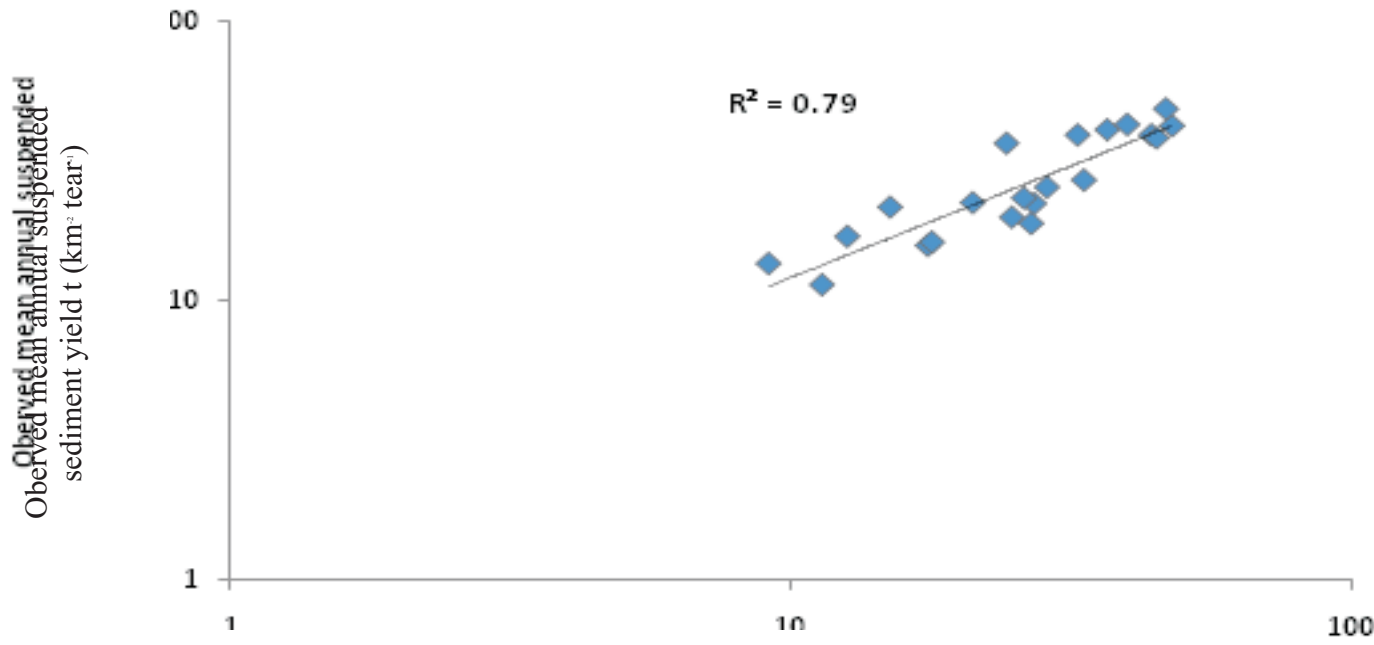

Fig.

Predicted mean annual suspended sediment yield $\left(\mathrm{t} \mathrm{km}^{2}\right.$ year')

Fig. 2. The plot of predicted and observed mean annual suspended sediment yields of Model 1

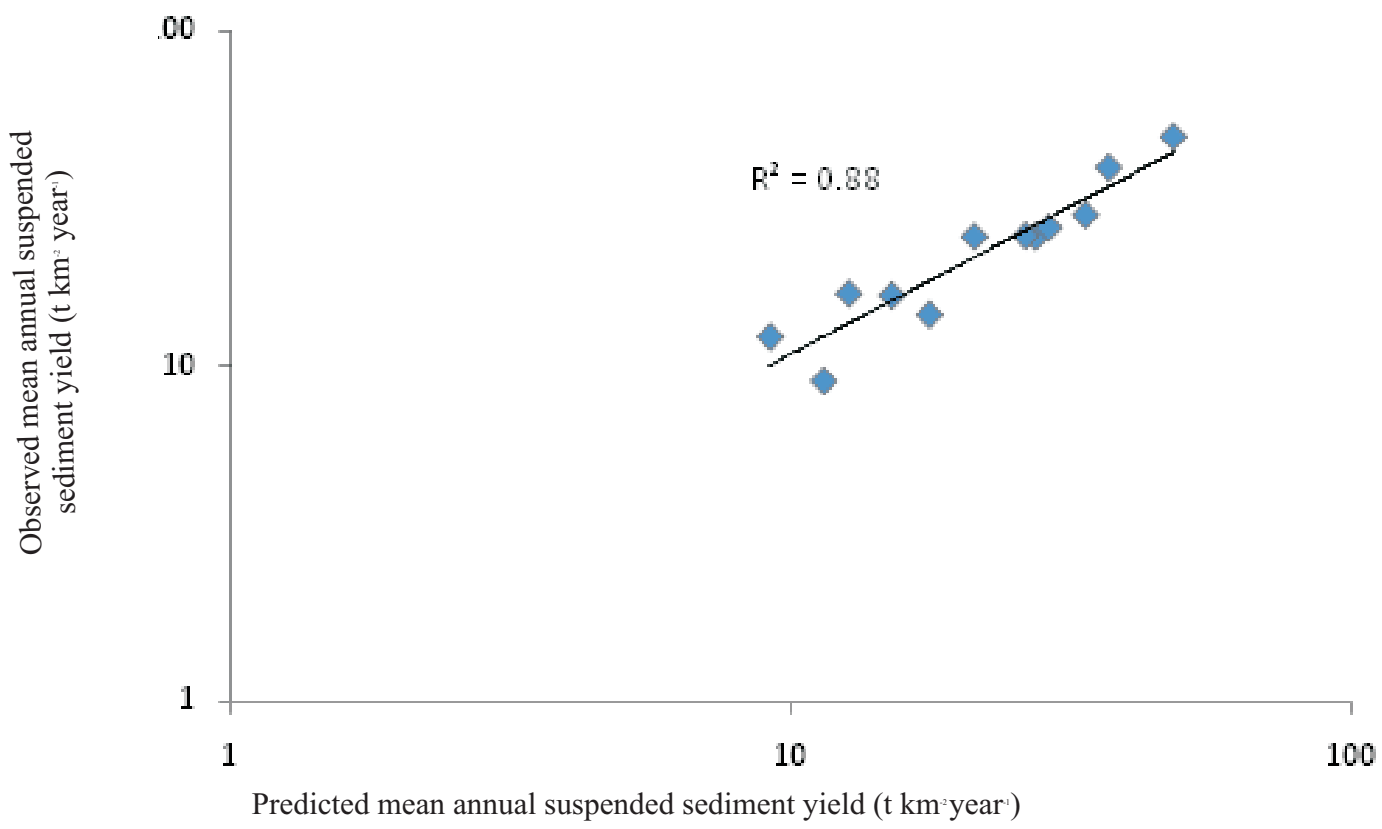

I Fig. 3. The plot of predicted and observed mean annual suspended sediment yields of Model 2 


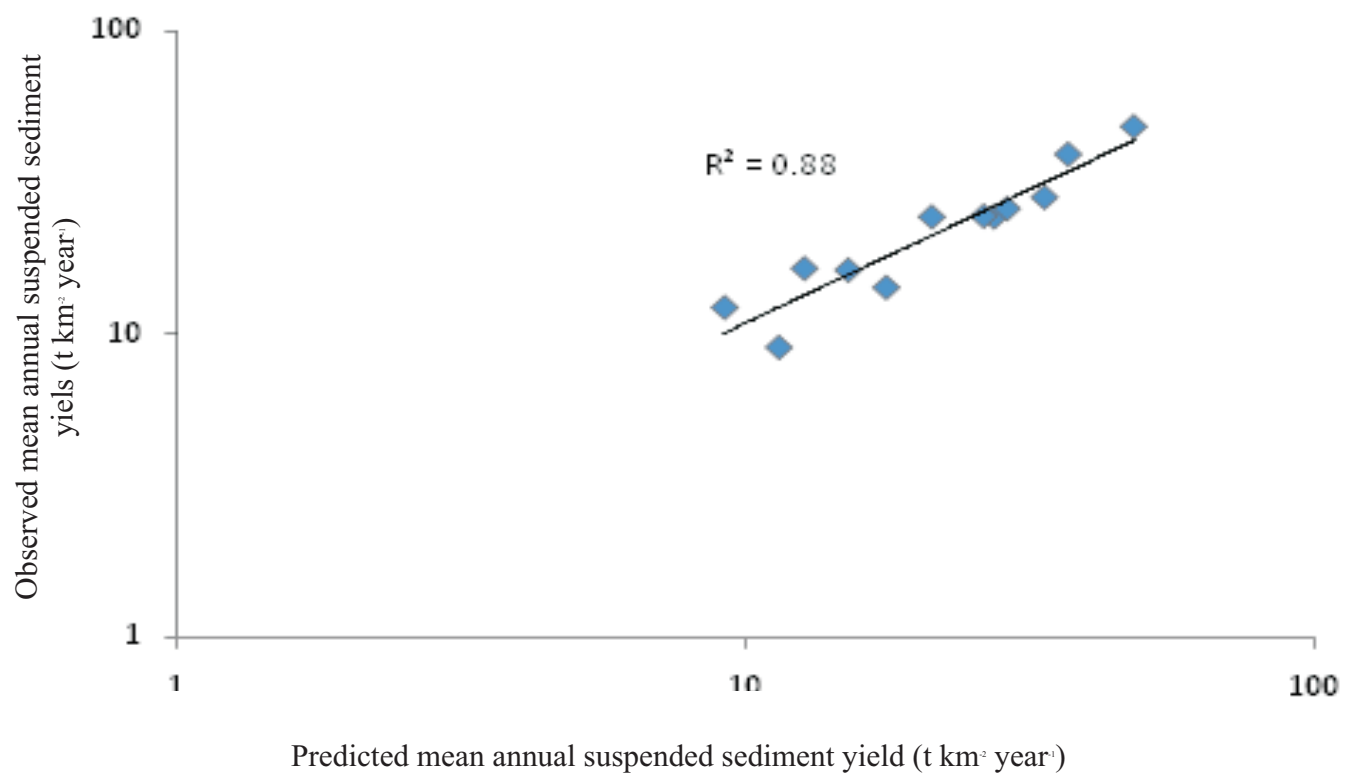

Fig. 4. The plot of predicted and observed mean annual suspended sediment yields of Model 3

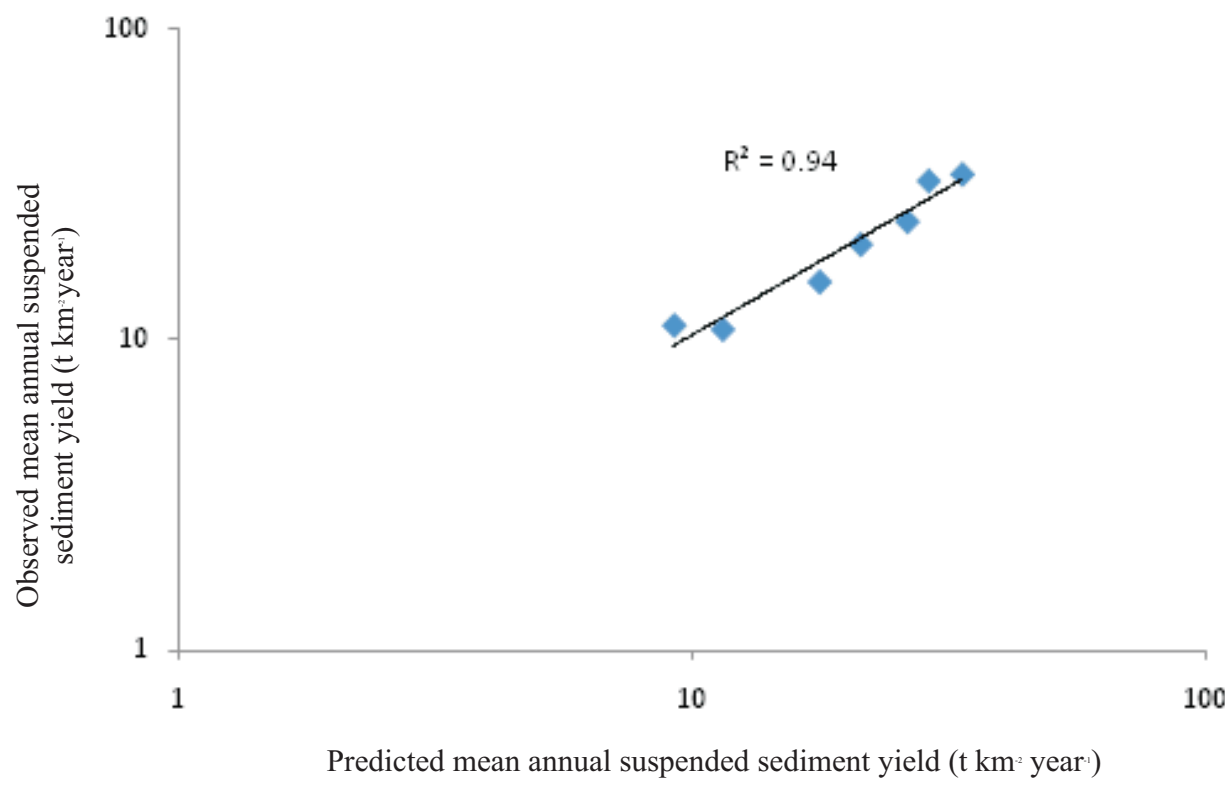

Fig. 5. The plot of predicted and observed mean annual suspended sediment yields of Model 4 
of specific suspended sediment yields across the south-western and coastal river basins, thereby, identifying the main areas that supply sediment to the sea. The reliability of the predictor is similar to one developed by Hydraulics Research for eastern and southern Africa using small dams (Lawrence, 2003). The coefficient of determination of the observed versus predicted values was $95 \%$. Model 3 was used to estimate the mean annual specific suspended sediment yields of the rivers catchment area. Table 2 presents the total sediment loads of the major rivers in the south-western and coastal basins after a 10\% bed load correction factor has been added to the suspended load. The correction factor was arrived after analysing the suspended sediment concentration and the type of material forming the channel of the river (Akrasi, 2008; Tilrem, 1979).

All the specific sediment yield values are low by world standards (Walling \& Webb, 1983 ), with a maximum of $49017 \mathrm{t} \mathrm{km}^{\prime 2}$ year" for River Pra and a minimum of $11.01 \mathrm{t} \mathrm{km}{ }^{\prime 2}$ year" ${ }^{\prime \prime}$ for River Tordzie. These low values reflect the low gradients of the river basins and the associated low-energy conditions and low efficiency of sediment delivery from the catchment surface to, and through, the channel system. The low efficiency of sediment delivery is further emphasized by the widespread evidence of sediment production within the basins from the surfaces of feeder roads, human settlements and illegal mining activities. Large amount of sediment produced in the basins might be redeposited in depressions and floodplains. The total sediment discharge from Ghanaian rivers into the sea was estimated to be H" 2.4 $\times 10^{6}$ tyear $^{\prime \prime}$.

The equivalent estimates of suspended sediment load and specific suspended sediment yield have been derived for the major rivers in the south-western and coastal river systems of Ghana (Table 3), togather with estimates from the Volta river basin. These values indicate that the specific suspended sediment yield of the Volta river basin is similar to that of the Amazon basin $\left(52.25 \mathrm{t} \mathrm{km}^{-2}\right.$ year $\left.{ }^{-1}\right)$ but significantly greater than that for the Congo $\left(16.19 \mathrm{t} \mathrm{km}^{-2}\right.$ year $\left.^{-1}\right)$ and Niger basins $\left(\mathrm{t} \mathrm{km}^{-2} \mathrm{year}^{-1}\right)$. Considered in

TABLE 2

Sediment discharge into the sea

\begin{tabular}{lccc}
\hline River & $\begin{array}{c}\text { Drainagearea } \\
\left(\mathrm{km}^{2}\right)\end{array}$ & $\begin{array}{c}\text { Sedimentyield } \\
\left(\mathrm{tkm}^{2} \text { year }\right)\end{array}$ & $\begin{array}{c}\text { Sediment discharge } \\
\text { tyear })\end{array}$ \\
\hline Bia & 10,135 & 25.53 & 258,747 \\
Tano & 16,061 & 24.14 & 387,713 \\
Ankobra & 8,366 & 48.15 & 402,823 \\
Butre & 422 & 35.34 & 14,913 \\
Pra & 23,168 & 49.17 & $1,139,171$ \\
Amisa & 1,298 & 27.49 & 35,682 \\
Nakwa & 1,409 & 35.85 & 50,513 \\
Ayensu & 1,709 & 16.75 & 28,626 \\
Tordzie & 2,916 & 11.01 & 32,105 \\
\hline
\end{tabular}


TABLE 3

Mean annual suspended sediment load and specific suspended sediment yield for the major rivers in the south-western and coastal river basins and the Volta river basin system

\begin{tabular}{lccc}
\hline River & $\begin{array}{c}\text { Drainage Area } \\
\left(\mathrm{km}^{2}\right)\end{array}$ & $\begin{array}{c}\text { Mean annual suspended } \\
\text { sediment load } \\
\left(\times 10^{6} \text { t year }\right)\end{array}$ & $\begin{array}{c}\text { Mean annual suspended } \\
\text { sediment yield } \\
\left(\mathrm{km}^{2} \text { year }\right.\end{array}$ \\
\hline Ankobra & 8,366 & $<1$ & 48.15 \\
Tano & 16,061 & $<1$ & 24.14 \\
Bia & 10,135 & $<1$ & 25.53 \\
Pra & 23,168 & 1 & 49.17 \\
Volta $\dagger$ & 400,000 & 17 & 52.25 \\
Black Volta $\dagger$ & 142,056 & 4 & 28.05 \\
White Volta $\dagger$ & 106,742 & 4 & 32.56 \\
Oti $\dagger$ & 75,110 & 5 & 63.26 \\
\hline
\end{tabular}

a broader context, however, the specific sediment yield of the rivers in Ghana must be interpreted as low when compared with that of the Ganges river $\left(1352.23 \mathrm{t} \mathrm{km}^{-2}\right.$ year $\left.^{-1}\right)$, which is more than an order of magnitude higher. The estimates of sediment discharge into sea and the specific sediment yield of the catchment of the rivers in the south-western and coastal basin systems of Ghana presented above relate specifically to the suspended sediment load.

\section{Conclusion}

Suspended sediment data within the southwestern and coastal river basin systems of Ghana have been analysed, and the yield and loads obtained have been used to develop simple empirical models predicting specific suspended sediment yields within the basins. All the statistics on the models showed that the models are reliable, and the parameters used for the formulation of the models have significant influence on the output functions.

The sediment yields in the south-western and coastal basins $\left(11-50 \mathrm{t} \mathrm{km}^{-2}\right.$ year $\left.^{-1}\right)$ may be considered to be low to moderate. They are, however, within the range of 3.9-85.0 t $\mathrm{km}^{-2}$ year $^{-1}$, obtained for some major rivers in various parts of West Africa (Walling, 1984). The total sediment loads carried by the rivers into the sea amounted to $2.4 \times 10^{6} \mathrm{t}$ per year. The total sediment load does not include sediment loads from the Densu and Volta rivers. The two rivers have dams across them close to the sea and sediment loads after the dams might be very low due to the significant reduction in flow rates.

Forest reserves, secondary forest, cocoa, coffee and oil palm plantations are the main land covers of the drainage basins. These vegetation types protect the soil from the erosive activity of rainfall that is very high within the basins. This might be the reason for the low sediment yield values. However, there is the need for comprehensive study to confirm this conclusion because there is very high density of feeder roads in the drainage basins. This, together with other activities such as over exploitation of timber trees by timber firms and excessive illegal tree felling for lumber, illegal gold and diamond winning, and slash and burn by farmers, are all major causes of forest degradation, which results in increased soil erosion and sediment production. 
Accurate estimates of suspended sediment load are essential for sediment budget investigations, since it may be necessary to compare the sediment yields of sub-basins to document the downstream changes in sediment loads occasioned by conveyance losses, or to investigate temporal trends in sediment yield. Though, transformation bias corrections were applied in this study, the load correction estimators have been proved to be unreliable (Walling \& Webb, 1988). The provision of reliable load estimates will, in many cases, necessitate the use of turbidity monitoring equipment or sensors, frequent sampling or the use of sampling strategies specifically designed to produce accurate load estimators. Daily suspended sediment sampling by surface dip by sampling assistants (Rooseboom \& Annandale, 1981) should be employed in Ghana to obtain accurate sediment load estimates.

\section{Acknowledgment}

The author wishes to thank the technical staff of the Surface Water Division of the CSIRWater Research Institute, Accra, for their cooperation and assistance in assembling the data used in this paper.

\section{References}

Akrasi S. A. (2005). The assessment of suspended sediment inputs to Volta Lake. Lakes \& Reservoirs: Research and Management 10: 179-186.

Akrasi S. A. (2008). Assessment of sediment transport in the south western and coastal river systems of Ghana. Water Research Institute, Water Resources Commission, Accra.

Akrasi S. A. and Ansa-Asare O. D. (2008). Assessing sediment and nutrient transport in the Pra basin of Ghana. West Afri. J. appl Ecol. 13: 61-73.

Akrasi S. A. and Amisigo B. A. (1993). Sediment loads of some major rivers in Ghana. Water Resources Research Institut, Technical Report. Accra.
Amisigo B. A. and Akrasi S. A. (2000). A suspended sediment yield predictive equation for river basins in the south western river basin system of Ghana. $J$. appl Sci. Techonol. 5(1 \& 2): 108-113.

Carvalho N. D. O. (1988). Sediment yields in the Velhas River Basin (Minas Gerais Brazil). In Sediment budgets (M. P. Bordas and D. E. Walling, eds), pp. 369-375. Proceedings of the Porto Alegre (Brazil) Symposium on Sediment Budgets 11-15 Dec. 1988, Porto Alegre, Brazil. IAHS Press, Wallingford, UK.

Dedkov A. P. (2004). The relationship between sediment yield and drainage basin area. In Sediment Transport Through the Fluvial System (V. Golosov, V. Belyaev and D. E. Walling, eds), pp. 197-204. IAHS Press, Wallingford, UK.

Demmak A. (1976). Note sur l'utilization de la "Turbisonade Neyrpic" pour l'élaboration d'un jaugeage de debit solide. Note Technique, No 114/SHYL, DEMRH, Algiers.

Dickson K. B. and Benneh G. (1980).. A New Geography of Ghana. Longman Group Limited, London.

Ferguson R. I. (1986). River loads underestimated by rating curves. Wat. Resour.Res. 22: 74-76.

Lawrence P. (2003). Predicting sedimentation rates in African small dams. Newsl. Wat. 16: 9.

Gregory K. J. and Walling D. E. (1973). Drainage Basin Form and Process. Edward Arnold, London.

Miller C.R. (1951). Analysis of flow duration sediment rating curve method of computing sediment yield. $\mathrm{U}$ S Bureau of Reclamation, Denver, Colorado, USA.

Rooseboom A. and Annandale G. W. (1981). Techniques applied in determining sedinent loads in South African rivers. In Erosion and Sediment Transport Measurement. (Proc. Florence Symp. June 1981). 219-224. IAHS Publ. No. 133.

Stocking M. (1984). Rates of erosion and sediment yield in the African environment In: Challenges in African Hydrology and Water Resources (Proc. Harare Symp., July 1984), 265-283. IAHS Publ. No.144.

Tilrem Q. A. (1979). Sediment transport in streams, sampling, analysis and computation. Vol. 5 of Manual on Procedures in Operational Hydrology.

Walling D. E. (1977). Assessing the accuracy of suspended sediment rating curves for a small basin. Wat. Resour. Res. 13: 531-538. 
Walling D. E. (1984). The sediment yields of African rivers. In Challenges in African Hydrology and Water Resources (Proc. Harare Symp., July 1984), 265-283. IAHS Publ. No.144.

Walling D. E. and Webb B. W. (1983). Patterns of sediment yield. In Background to Palaeohydrology (K. J. Gregory, ed.), pp. 69-100. Wiley, Chichester.

Walling D. E. and Webb B. W. (1988). Reliability of rating curve estimates of suspended sediment yield: some further comments. In Sediment Budgets (Proc.
Porto Alegre Symp., Dec. 1988) 337-350. IAHS Publ. No. 174.

Walling D. E. and Webb B. W. (1996). Erosion and sediment yield: Global overviews. In Erosion and Sediment Yield: Global and Regional Perspectives (D.E. Walling \& B. W. Webb, ed.), pp. 3-19. IAHS Press, Wallingford, UK.

Yamane T. (1970). Statistics: An Introductory Analysis. International edn. Harper \& Row, New York. 